\title{
PLK3 Gene
}

National Cancer Institute

\section{Source}

National Cancer Institute. PLK3 Gene. NCI Thesaurus. Code C24302.

This gene is involved in the regulation of mitosis. 